\title{
Interpersonel farvning i dansk
}

\author{
Thomas Hestbak Andersen og Flemming Smedegaard \\ Institut for Sprog og Kommunikation, Syddansk Universitet, Danmark
}

Interpersonal colouring in Danish. On a systemic functional background this paper presents two central interpersonal resources in Danish, namely the concept of speech function and the concept of modality. Thus, the paper presents linguistic ways to negotiate meaning and to express attitude. The negotiation of meaning and the expression of attitude can be dealt with in both a typical way and a non-typical way. The typical way constitutes the congruent and non-metaphorical mode while the latter constitutes the incongruent mode and thereby the lexicogrammatical metaphor. The paper examines both nonmetaphorical and metaphorical ways of negotiating meaning and expressing attitude.

I denne artikel præsenterer vi to centrale interpersonelle ressourcer i sproget. Disse ressourcer farver en sproglig ytring, så den (i) fungerer i udvekslingen af information mellem en afsender og en modtager (fx er det ikke ligegyldigt, om man siger roek mig saltet!, roekker du mig saltet? eller saltet står ovre hos dig...) og (ii) virker til at markere afsenders attitude til den information, han videregiver ( $\mathrm{fx}$ har det betydning, hvor sikkert man udtaler sig: Der er væsentlig mere overbevisning i Tak for invitationen; jeg kommer end i Tak for invitationen; jeg kommer måske).

Ressourcerne til udveksling af information mellem afsender og modtager beskriver vi som sprogets ytringsfunktioner, og ressourcerne til at markere afsenders attitude beskriver vi som sprogets modalitet. Disse ressourcer kan anvendes både typisk og atypisk, og vi vil beskrive begge ressourcer i begge anvendelser.

Vores beskrivelse af de interpersonelle ressourcer i dansk er baseret på den systemisk funktionelle teori om sprog. Dette fundament vil vi derfor indledningsvis kort præsentere.

\section{Det SYSTEMISK FUNKTIONELLE FUNDAMENT}

Language is as it is because of what it has to do.

(Halliday 1978: 19)

Ovenstående citat udtrykker efter vores overbevisning kort og koncist den systemisk funktionelle opfattelse af, hvad 'sprog' er for en størrelse, og hvordan det fungerer. Hallidays ord kan elaboreres med Hasans, idet hun påpeger, at 
Thomas Hestbæk Andersen og Flemming Smedegaard, Interpersonel farvning i dansk

\begin{abstract}
"The thrust of the functional hypothesis is not just that language is useful; it is rather that the lexicogrammatical form of the language has developed and is as it is because of the meanings that the speakers perceived the need to create." (Hasan 1985: 6)
\end{abstract}

Med en tro på ovenstående opfattelser følger, at en sprogbeskrivelse må tage højde for, at sprog er betydningsgenererende og -gengivende, og at dets funktionalitet er at fungere i en kontekst netop som betydningsgenererende og -gengivende. Tekst (sprogliggjort virkelighed) og kontekst (virkelighed) er med andre ord interdependente størrelser: Konteksten indvirker på sproget på en sådan måde, at dets organisering er en direkte følge af de krav, virkeligheden stiller til sprogets evne til at fungere som kommunikationsmiddel, og sproget virker tilbage på konteksten ved med sine kategorier (ikke mindst sin grammatik) at organisere forståelsen af virkeligheden (jf. Halliday 1996: $4){ }^{1}$

Sprogets grammatik er altså naturlig og ikke-arbitrær forstået på den måde, at dets kategorier er fordret af dets omgivelser (konteksten) for at skabe betydning. Dermed er det også sådan, at ikke blot sammenhængen mellem kontekst og grammatik er naturlig og et resultat af ubevidst evolution frem for bevidst design (jf. Halliday 1984: 309), det er også tilfældet, at sammenhængen mellem betydning (: semantik) og betydningens sprogliggørelse i ord (: leksikogrammatik) er naturlig.

Sammenhængen mellem kontekst, semantik og leksikogrammatik ${ }^{2}$ er stratifikationel på en sådan måde, at konteksten realiseres af semantikken, som igen realiseres af leksikogrammatikken. Konteksten er sprogets omgivelser, mens semantikken og leksikogrammatikken betegner sprogets 'indhold'sstrata, idet det er på disse strata, at sproget betydningsskabende ressourcer findes. Denne stratale opfattelse kan visualiseres med koncentriske cirkler, som det er gjort i fig. 1 nedenfor. 
Thomas Hestbæk Andersen og Flemming Smedegaard, Interpersonel farvning i dansk

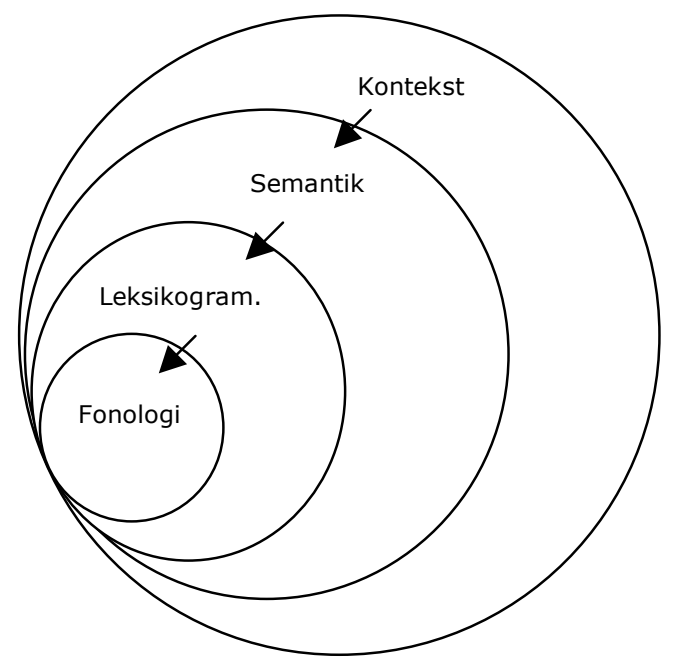

Fig. 1: Stratifikation

I fig. 1 har vi tilføjet et i denne artikel hidtil ubeskrevet stratum, nemlig fonologien. Dette stratum realiserer leksikogrammatikken, idet det lydligt 'udtrykker' de sproglige betydninger, som skabes på det leksikogrammatiske og det semantiske stratum.

I forhold til menneskets fysik og dets omgivelser fungerer de fire strata som beskrevet af Halliday:

"The expression system (prototypically, the phonology) interfaces with the human body; the (semantic component of the) content interfaces with the entire realm of human experience; whereas the grammar evolves as an interface between these two interfaces - shoving them apart, so to speak, in such a way that there arises an indefinite amount of 'play' between the two." (Halliday 1996: 6)

Vi har ovenfor betegnet semantikken og leksikogrammatikken som 'indhold', hvortil fonologien svarer som 'udtryk'. Hermed har vi indikeret, hvor sproget er arbitrært i saussuresk forstand (jf. Saussure 1949) - nemlig der, hvor sprogets semantiske og leksikogrammatiske funktioner skal finde en lydlig realiseringsmåde. ${ }^{3}$

Når man foretager en sprogbeskrivelse, kan man i relation til stratifikation principielt begynde 'fra neden', altså i leksikogrammatikken, og så arbejde sig op og videre til betydning og kontekst, eller man kan begynde 'fra oven', altså i konteksten, og så arbejde sig ned gennem betydning til leksikogrammatik. Som en del af lingvistikkens funktionelle paradigme lægger den systemisk funktionelle lingvistik sin vægt på perspektivet fra oven, hvorved semantiske og leksikogrammatiske kategorier motiveres fra konteksten og derved fra deres kommunikative bidrag. 
Thomas Hestbæk Andersen og Flemming Smedegaard, Interpersonel farvning i dansk

Konteksten betragter vi som "the total environment in which a text unfolds" (Halliday \& Hasan 1985: 5) - eller udtrykt på en anden måde: Konteksten er den situation, hvori en tekst fungerer og skaber betydning. I forlængelse heraf benævnes konteksten i systemisk funktionel sammenhæng den situationelle kontekst, og den udgøres af variablerne (i) felt, (ii) tenor og (iii) måde (jf. Andersen et al. 2001: 258).

Felt fokuserer på, hvilken erfaring der er central, og som udveksles i den sociale situation, der omgiver teksten. Udtrykt på anden vis fokuserer felt på, hvad der kommunikeres om. Tenor fokuserer på relationen mellem afsender og modtager - eller med andre ord fokuserer tenor på, hvilket forhold de kommunikerende parter har til hinanden. Det drejer sig om, hvem der kommunikerer med hvem og med hvilket formål. Måde fokuserer på sprogets rolle i interaktionen mellem afsender og modtager. Det drejer sig om teksten som udvekslingsmedium, altså hvordan der kommunikeres.

De tre kontekstuelle variabler, felt, tenor og måde, realiseres sprogligt på først det semantiske og videre det leksikogrammatiske stratum. Dette er illustreret med pile i fig. 1. Realiseringen fungerer gennem tre metafunktioner. Således har feltet sin sproglig pendant i sprogets ideationelle metafunktion, tenoren har sin sproglige pendant i sprogets interpersonelle metafunktion, og måde har sin sproglige pendant i sprogets tekstuelle metafunktion (jf. Halliday 1979: 78). Metafunktionerne er sameksisterende og bidrager på hver sin måde til, at sproget fungerer og lever op til de krav, vi har til det. Disse krav er med Jakobsens ord for det første, at sproget skal fungere som kommunikationsmiddel, og for det andet, at sproget skal "modsvare menneskets kognitive, fysiologiske og sociale færdigheder" (Jakobsen 1995: 11).

Den ideationelle metafunktion drejer sig om ideationen, idet den repræsenterer de ressourcer, vi betjener os af for at konstruere vores erfaring med verden omkring os og inden i os. På denne vis er den ideationelle metafunktion

"[...] concerned with the content of language, its function as a means of the expression of our experience, both of the external world and of the inner world of our own consciousness - together with what is perhaps a separate sub-component expressing certain basic logical relations." (Halliday 1973: 66)

Den interpersonelle metafunktion udspringer af interaktionen mellem afsender og modtager. Den stiller de ressourcer til rådighed, som vi trækker på, når vi spiller vores forskellige roller i interaktionen ved hjælp af ytringsfunktioner og modal farvning. Således fungerer den interpersonelle metafunktion som

"[...] the mediator of role, including all that may be understood by the expression of our own personalities and personal feelings on the one hand, and forms of interaction and social interplay with other participants in the communication situation on the other hand." (Halliday 1973: 66) 
Thomas Hestbæk Andersen og Flemming Smedegaard, Interpersonel farvning i dansk

Den sidste af metafunktionerne, nemlig den tekstuelle, betegner sprogets funktion til diskursivt - altså som "text in context" (Matthiessen 1992: 18) - at organisere ideationel og interpersonel betydning i teksten, som den udfolder sig i en interaktion. Således betegner den tekstuelle metafunktion

"[...] language in operation as distinct from strings of words or isolated sentences and clauses. It is the component that enables the speaker to organize what he is saying in such a way that it makes sense in the context and fulfils its function as a message." (Halliday 1973: 66)

Som allerede angivet i indledningen er det den interpersonelle metafunktion og dennes sproglige ressourcer, vi i denne artikel præsenterer. Således vil vi nedenfor beskrive (i) de sproglige ressourcer, der gør sproget brugbart i udvekslingen af (ideationel) information mellem en afsender og en modtager (disse ressourcer er sprogets ytringsfunktioner og deres leksikogrammatiske realisering), og (ii) de sproglige ressourcer, hvorved afsender farver sit (ideationelle) budskab med en interpersonel attitude (disse ressourcer er sprogets modalitet og modalitetens leksikogrammatiske realisering).

\section{YTRINGSFUNKTIONER OG DERES REALISERING I DANSK}

Formålet bag en sprogbrug danner baggrund for den systemisk funktionelle taksonomi over ytringsfunktioner ${ }^{4}$. Ytringsfunktionerne er semantiske størrelser, der fremkommer ud fra de to interpersonelle kontekstuelle aspekter, der er i spil i enhver kontekst. Disse aspekter knytter sig (i) til afsenders (og dermed modtagers) rolle i kommunikationen og (ii) til den sag, der udveksles mellem afsender og modtager.

Med hensyn til (i) kan man fundamentalt set spille en af to roller: Man kan enten være giver eller anmoder. Således anvendes sprog interpersonelt grundlæggende med det formål enten at give eller at anmode om et eller andet. Dette et eller andet er det, der udveksles mellem afsender og modtager (jf. (ii)), og også her kan en tvedeling foretages: Man kan enten udveksle information eller ting-\&-serviceydelser.

De to ovennævnte aspekter realiseres i semantikken som sprogets ytringsfunktioner, der fremkommer ved, at de krydses. En sådan krydsning resulterer i fire basale ytringsfunktioner, nemlig (i) udsagn (give information), (ii) spørgsmål (anmode om information), (iii) tilbud (give ting- $\&$-serviceydelser) og (iv) opfordring (anmode om ting-\&-serviceydelser) (jf. Andersen et al. 2001: 37). Dette er illustreret i fig. 2.

\begin{tabular}{|l|c|c|}
\hline ROLLE & SAG & TING-\& \&-SERVICEYDELSER \\
\hline GIVER & udsagn & tilbud \\
\hline ANMODER & spørgsmål & opfordring \\
\hline
\end{tabular}

Fig. 2: Basale ytringsfunktioner 
Thomas Hestbæk Andersen og Flemming Smedegaard, Interpersonel farvning i dansk

En ytringsfunktion, hvis formål er udvekslingen af information, benævnes en proposition (som altså er en samlebetegnelse for udsagn og spørgsmål), mens en ytringsfunktion, hvis formål er udvekslingen af ting-\&-serviceydelser, benævnes et proposal (som altså er en samlebetegnelse for tilbud og opfordring).

Som allerede nævnt under præsentationen af sprogets metafunktioner fungerer sproget på samme tid som en mekanisme til at etablere interpersonelle relationer og til at udveksle budskaber (ideationel betydning) mellem afsender og modtager. Af dette følger, at det er muligt at skelne mellem den del af en sprogbrug, der har særlig betydning for sprogets interpersonelle kvaliteter, og den del, der primært er bærer af ideationel betydning. Hvordan dette kommer frem i praksis, kan illustreres med nedenstående (konstruerede) samtale mellem A, B og C. I samtalen er den særligt interpersonelle del af hver ytring markeret med en understregning.
A: Hvor skal vi spille kort $i$ aften?
B: Vi skal spille hos Albert.
C: Nej, vi spiller oppe hos Laura.
B: Spiller vi hos Laura?
C: Ja, det aftalte vi da sidst.
B: Aftalte vi ikke at mødes hos Albert.
C: Nej.
B: Nå, jamen så spiller vi hos Laura.
A: Ja, det har jeg så forstået. Hvor bor hun?

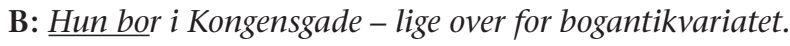
A: $O K \ldots$

Den særligt interpersonelle del af hver ytring realiseres i leksikogrammatikken af Moduselementet i en sætning - det er den del, vi i ovenstående samtale har understreget. Ud fra samtalen er det tydeligt, at Modus ikke rummer den (ideationelle) information, der udveksles, men derimod hele tiden genoptager de samme elementer, nemlig de personer, der grundlæggende er ansvarlige for ytringernes sandhedsværdi (syv gange vi, en gang jeg og to gange hun) samt de temporale og modale aspekter af ytringernes betydning. Modus rummer således de funktioner i hver ytring, som bærer udvekslingen/ samtalen som helhed fremad. Den resterende del af ytringen, som vi benævner Residual, rummer den ideationelle betydning, der udveksles.

Forskellen og komplementariteten mellem Modus og Residual kan uddybende anskues på følgende måde: I Residual realiseres betydning, der afspejler en generisk situation, fx købe en togbillet. Ved at tilføje Modus til Residual forankrer vi den generiske situation; den bliver konkret, fordi vi tilskriver tid, og fordi vi tilskriver den person, der er ansvarlig for, at den generiske situation bliver en konkret hændelse i verden. I forhold til købe en togbillet kunne vi forestille os et Modus som Albert vil, og vi vil få udsagnet Albert vil købe en togbillet. ${ }^{5}$ Konkretiseringen af en eller anden generisk situation er nødvendig for, at vi kan argumentere om den - for at vi kan afgøre, om den er sand eller falsk, og hvordan 
Thomas Hestbæk Andersen og Flemming Smedegaard, Interpersonel farvning i dansk

vi skal reagere på den. På denne vis rummer Modus sprogets ressourcer til forhandling, og dets interpersonelle farvning er tydelig.

Et nøjere blik på Modus viser, at vi her finder to typer af funktioner, der er afgørende i den leksikogrammatiske realisering af ytringsfunktionerne. Disse funktioner er Finitum og Subjekt. Finitum er den funktion i en sætning, der rummer sætningens temporalitet, ligesom den kan rumme modalitet. Formalt realiseres Finitum af den finitte del af sætningens verbalgruppe, fx Albert vil loese artiklen i påsken. Subjekt er den funktion i en sætning, der er ansvarlig for, om sætningsbetydningen (den propositionelle/ proposale betydning) står til troende eller ej. ${ }^{6}$ Formalt realiseres Subjekt af en nominalgruppe, en infinitivsætning eller en sætning med status af en gruppe, $\mathrm{fx}$ Albert vil loese artiklen i påsken. Hvor der er markering for kasus (altså hvis Subjektet udgøres af et personligt pronomen), står Subjekt i nominativ.

Ud over Finitum og Subjekt rummer Modus en række Adjunkter, som ikke har direkte betydning for realiseringen af ytringsfunktioner, men som for fuldstændighedens skyld skal anføres. Adjunkterne kan tilskrive modalitet, deiktisk tid, styrke eller polaritet, og de realiseres formalt af adverbier eller af præpositionalfraser. Nedenstående er eksempler på forskellige typer af Adjunkter:
Albert vil måske loese artiklen i påsken.
(modalitet)
Albert vil nu loese artiklen.
(deiktisk tid)
Albert vil selvfølgelig loese artiklen i påsken. (styrke)
Albert vil ikke loese artiklen i påsken.
(polaritet)

Moduselementets funktioner er konstituerende for den finitte sætning i dansk, idet det er distributionen af Finitum og Subjekt, som afgør, hvilken sætningsstruktur der er tale om:

- Imperativen er kendetegnet ved at rumme Finitum/Prædikator ${ }^{7}$, fx Spil så det klør es, Albert!

- Deklarativen rummer Finitum og Subjekt, men i en fakultativ rækkefølge, fx Albert vil spille klør es til sidst (Subjekt efterfulgt af Finitum) og Til sidst vil Albert spille klør es (Finitum efterfulgt af Subjekt).

- Interrogativen findes $\mathrm{i}$ to typer; polarinterrogativen er karakteristisk ved rækkefølgen Finitum efterfulgt af Subjekt, fx Vil du aldrig spille det klør es?, mens indholdsinterrogativen dannes af et hv-spørgeord efterfulgt af Finitum, fx Hvorfor vil du ikke spille klør es?

Ovenstående sammenhænge kan skitseres som netværket i fig. 3 nedenfor. 
Thomas Hestbæk Andersen og Flemming Smedegaard, Interpersonel farvning i dansk

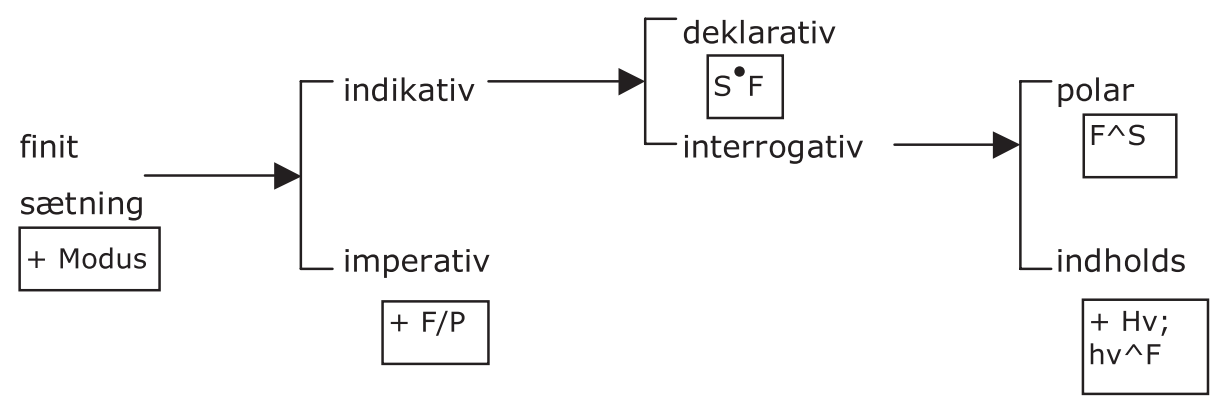

Fig. 3: Sætningsstrukturer i dansk

Sammenhængene mellem sætningsstrukturer og ytringsfunktioner er, at (i) udsagnets typiske realisering er deklarativen, (ii) spørgsmålets typiske realisering er interrogativen (både som hv-interrogativ og som polarinterrogativ), (iii) opfordringens typiske realisering er imperativen og (iv) tilbuddets typiske realisering er modalinterrogativen. Denne sammenhæng er skitseret i fig. 4.

\begin{tabular}{|l|l|l|l|}
\hline BETYDNING & YTRINGSFUNKTION & SAETNINGSTYPE & EKSEMPEL \\
\hline $\begin{array}{l}\text { GIVNING AF } \\
\text { INFORMATION }\end{array}$ & udsagn & deklarativ & Jeg føler mig syg. \\
\hline $\begin{array}{l}\text { SøGNING EFTER } \\
\text { INFORMATION }\end{array}$ & spørgsmål & interrogativ & $\begin{array}{l}\text { Er du syg? } \\
\text { Hvor føler du dig } \\
\text { syg? }\end{array}$ \\
\hline $\begin{array}{l}\text { SøGNING EFTER TING- } \\
\text { \&-SERVICEYDELSER }\end{array}$ & opfordring & imperativ & Tag til loegen! \\
\hline $\begin{array}{l}\text { GIVNING AF TING-\&- } \\
\text { SERVICEYDELSER }\end{array}$ & tilbud & modalinterrogativ & $\begin{array}{l}\text { Kan jeg køre dig } \\
\text { til loegen? }\end{array}$ \\
\hline
\end{tabular}

Fig. 4: Ytringsfunktioner og deres typiske realiseringer

Med fig. 4 har vi fuldført bevægelsen fra semantikkens ytringsfunktioner til den realiserende leksikogrammatik og tilbage igen, hvorved denne type sprogbrug er blevet beskrevet såvel 'fra oven' som 'fra neden'. 
Thomas Hestbæk Andersen og Flemming Smedegaard, Interpersonel farvning i dansk

\section{ModALITET OG DENS REALISERING I DANSK ${ }^{8}$}

I sproget har vi både en positiv og en negativ pol, fx forskellen på jeg kommer og jeg kommer ikke. Positiv polaritet er umarkeret på dansk, mens negativ polaritet markeres med indsættelsen af en af Polaritetsadjunkterne $i k k e$ eller $e j$.

Det er imidlertid langtfra altid, at vi ønsker at betegne en situation entydigt positivt eller entydigt negativt. Sproget rummer derfor mange muligheder for gradueringer mellem ja og nej. Disse gradueringer finder vi i sprogets modalitetsressourcer, som Halliday i forlængelse af ovenstående betragter som rummet mellem ja og nej:

"Polarity is thus a choice between yes and no. But these are not the only possibilities; there are intermediate degrees, various kinds of indeterminacy that fall in between, such as 'sometimes' or 'maybe'. These intermediate degrees, between the positive and negative poles, are known collectively as MODALITY. What the modality system does is to construe the region of uncertainty that lies between 'yes' and 'no'." (Halliday \& Matthiessen 2004: 146f.)

Modalitet er et interpersonelt koncept, for semantisk betegner modalitet afsenders attitude i forhold til den propositionelle/ proposale betydning i en ytring.

Vi kan skelne mellem forskellige typer af modalitet, som knytter sig til de forskellige typer af ytringsfunktioner, som er beskrevet $\mathrm{i}$ afsnit 2. Vi kan overordnet skelne mellem (i) modalisation', som betegner modalitet i forbindelse med propositioner (ytringsfunktionerne udsagn og spørgsmål i forbindelse med givning og søgning af information), og (ii) modulation ${ }^{10}$, som betegner modalitet i forbindelse med proposaler (ytringsfunktionerne opfordring og tilbud i forbindelse med søgning og givning af ting \& serviceydelser).

I propositioner forhandles der om, hvorvidt noget er eller ikke er, dvs. polerne udgøres af er og er ikke. Afsender kan så graduere sit udsagn eller spørgsmål ved at specificere grader af muligheder og sandsynligheder og/ eller grader af vanlighed. Vi kan således i modalisation skelne mellem to subtyper, nemlig henholdsvis (i) mulighed \& sandsynlighed, og (ii) vanlighed.

I proposaler udgøres polerne af $g ø r$ og $g ø r$ ikke. Mellem disse poler kan der optræde en række gradueringer, således at vi i modulation også kan skelne mellem to subtyper, nemlig henholdsvis (i) hæftelse, og (ii) tilladelse. Hæftelse kan videre specificeres i (i) selvforpligtelse, som er 1. persons hæftelse, (ii) forpligtelse, som er 2. persons hæftelse, og (iii) nødvendighed, som er 3. persons hæftelse.

Leksikogrammatisk realiseres modalitet af systemet MODALITET. Den leksiko-grammatiske realisering sker på typisk vis gennem sætningens Modus-element, og realiseringen kan foregå ved hjælp af henholdsvis modalverber (fx I højsommeren kan den fugtige varme voere en plage) og Modaladjunkter (fx Priserne bliver antagelig først fastsat $i$ august eller september).

I det følgende vil vi eksemplificere, hvordan de forskellige typer af modalitet realiseres leksikogrammatisk. 
Thomas Hestbæk Andersen og Flemming Smedegaard, Interpersonel farvning i dansk

Mulighed \& sandsynlighed realiseres væsentligst af en lang række forskellige Modaladjunkter, fx:

De kommer antagelig til København til oktober.

Det betyder antageligvis ikke noget.

AEldresiden bliver efter alt at dømme netop et af satsningsområderne.

Det skyldes formentlig stress.

Det var formodentlig chokoladesovs fra flaske.

Det vil forventelig igen voere samfundets svageste, som rammes.

Kanske det var derfor, han følte sig forurettet.

Hvornår mon virkeligheden går op for danskerne?

Det bliver muligvis afgiort allerede på onsdag.

Det har måske også voeret medvirkende til, at vi ikke er nået loengere.

I det virkelige liv gør det noeppe den store forskel.

Man skal rimeligvis vaere en stoerk person for at sige Brixtofte imod.

Ideen fra Vestsjoelland kan sagtens bruges andre steder.

Grunden er sandsynligvis, at moendene er så vilde med os.

Det hele var tilsyneladende kun lagt an på et utrovoerdigt vidne.

Det hører vel med til jobbet?

Kvartetten med Luc Leblanc udgør vel nok den alvorligste trussel.

Men han vurderede vel sagtens kun holdets proestation i den kamp.

Han nåede vist at smutte, inden politiet kom.

Klubben arbejder vistnok på at udsende et eller andet.

Af modalverber er det primært kunne, som realiserer mulighed \& sandsynlighed, fx Malaria kan også vise sig langt senere, men også et modalverbum som måtte, fx I hvert fald to socialdemokrater må voere blevet klogere efter den seneste tid, kan realisere mulighed \& sandsynlighed.

Ikke-realiseret propositionel betydning, irrealis, hører også hjemme under modalisationstypen mulighed \& sandsynlighed, fx: Hvis han vidste det, ville han sige det (men da han sandsynligvis ikke ved det, så siger han ikke noget) og Jeg ville rejse jorden rundt, hvis jeg vandt. (men da jeg sandsynligvis ikke vinder, gør jeg det ikke).

Vanlighed kan ikke realiseres af modalverber, men kun af Modaladjunkter, fx:

Der vil for det meste voere tale om rene bagateller.

Der vil hyppigt voere tale om noget helt ufarligt.

De er mestendels til ulden tale og verbalakrobatiske helgarderinger.

Telestyrelsen vil oftest voere første sted, man skal klage.

Det bliver sjoeldent sagt $i$ en ond mening.

Han vil som regel vaere den første, der kommer.

Hun kommer saedvanligvis i kirken om søndagen.

Medicinen kan undertiden have uønskede bivirkninger. 
Thomas Hestbæk Andersen og Flemming Smedegaard, Interpersonel farvning i dansk

Socialdemokrater og Konservative vil undtagelsesvis gå sammen.

Forretten er vanligvis forskellige antipasta.

Altid og aldrig betragtes også som realiserende modalitet (og ikke polaritet). Et eksempel som Jeg kommer altid betegner, at afsender i særlig grad har brug for at understrege, at han altid kommer, fx som svar på en kritik. Hvis afsender var $100 \%$ sikker i sin sag, kunne han blot anvende positiv polaritet og sige Jeg kommer. På samme måde realiserer Jeg kommer aldrig en forstærkende usikkerhed. Hvis afsender var sikker i sin sag, kunne han her blot anvende negativ polaritet og sige Jeg kommer ikke.

Det er værd at være opmærksom på, at det ikke er alle Modusadjunkter, der realiserer tid, som også realiserer modalitet. Eksempler på Modusadjunkter, der realiserer tid, men ikke modalitet, er fx Hun kom pludselig, Han er her allerede, Er du her endnu? og Venter du stadig?

Ligeledes må Modaladjunkterne, der omhandler vanlighed, ikke forveksles med de Cirkumstantialeadjunkter ${ }^{11}$, som realiserer en tidslig betydning (fx Han vil komme i morgen, Der afholdes generalforsamling en gang om året og De bliver her i to uger). Cirkumstantialeadjunkterne kan kendes ved, at de altid kan placeres i sætningens Residual efter Prædikator (fx Han vil komme i morgen), mens Modusadjunkter aldrig kan placeres i Residual efter Prædikator, (fX *Han vil komme saedvanligvis), men kun i Modus enten mellem Finitum og Prædikator (Han vil soedvanligvis komme) eller i begyndelsen af sætningen (Soedvanligvis vil han komme).

Hæf telse realiseres først og fremmest af modalverber, primært skulle, burde og måtte, men kan også realiseres af enkelte Modaladjunkter, bl.a. nødvendigvis, absolut, for enhver pris, for alt $i$ verden, fuldstoendig og partout.

Hæftelse kan som nævnt specificeres i tre subtyper:

(i) Selvforpligtelse, som omhandler 1. persons hæftelse, fx:

Vi skal holde sammen i Danmark - og i verden.

Jeg bør snart se at komme hjem.

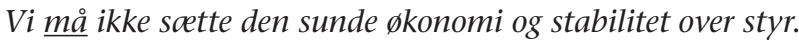

Vi skal absolut komme allerede kl. 4.

Jeg må nødvendigvis hjoelpe til.

(ii) Forpligtelse, som omhandler 2. persons hæftelse, fx:

Du skal stadig drikke rigeligt med voeske.

$\mathrm{Nu}$ skal du bare høre efter.

Du burde ikke have ladet stå til i så lang tid.

Omvendt $\underline{\text { må }}$ du nødvendigvis sloekke noget på egne ønsker.

(iii) Nødvendighed, som omhandler 3. persons hæftelse, fx: 
Thomas Hestbæk Andersen og Flemming Smedegaard, Interpersonel farvning i dansk

Evaluering skal indrapporteres til studielederen.

Børnene bør ikke voere i institution i mere end 8 timer.

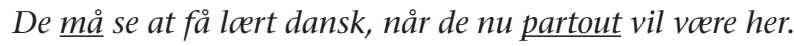

Tilla dels e realiseres først og fremmest af modalverbet kunne, men kan også realiseres af modalverber som burde, måtte og skulle. I enkelte tilfælde kan tilladelse også realiseres af Modaladjunkter, bl.a. gerne og naturligvis, fx:

Du kan bare tage, hvad du vil have.

Det $\underline{\text { må }}$ du gerne gøre.

Det skal du voere velkommen til at gøre.

De står naturligvis frit.

Det leksikogrammatiske netværk for MODALITET er skitseret på næste side i fig. 5 . 
Thomas Hestbæk Andersen og Flemming Smedegaard, Interpersonel farvning i dansk

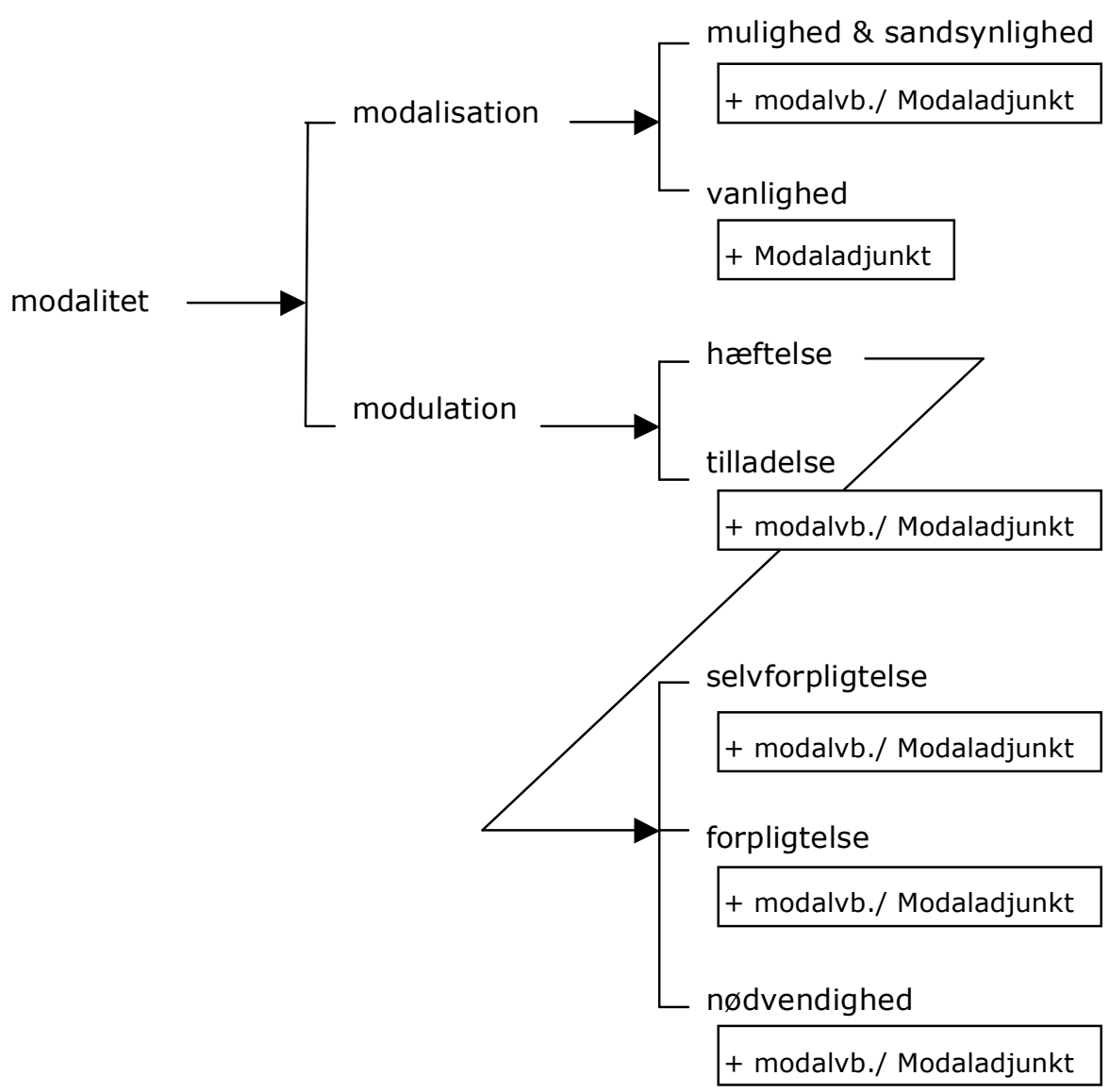

Fig. 5: Leksikogrammatisk netværk for MODALITET

\section{ET EKSTRA BLIK PÅ YTRINGSFUNKTIONER OG MODALITET: INTERPERSONEL METAFORIK}

I artiklens afsnit 2 og 3 har vi givet en semantisk og leksikogrammatisk beskrivelse af sprogets to primære interpersonelle ressourcer, nemlig ytringsfunktionerne og disses sammenhæng med danske sætningsstrukturer samt modalitet og dennes leksikogrammatiske realisering i den danske sætnings Modus-element, som billedet typisk er. Som et perspektiv herpå vil vi i dette afsnit kort betragte de to interpersonelle ressourcer, når de bringes i spil på atypisk vis. Vi vil med andre ord præsentere hovedtyperne af interpersonelle leksikogrammatiske metaforer i dansk. ${ }^{12}$

Før vi kan beskrive metaforerne, som altså kendetegner det atypiske, er det for det første nødvendigt at vide præcist, hvad typisk er - hvilken typikalitet, vi regner ud fra. For det andet har vi brug for en teoretisk model af den leksikogrammatiske metafor. 
Thomas Hestbæk Andersen og Flemming Smedegaard, Interpersonel farvning i dansk

I artiklens to foregående hovedafsnit har vi beskrevet det typiske for de konkrete sproglige ressourcer, vi har behandlet. Vi har således givet et deskriptivt signalement. Inden vi fortsætter vil vi give distinktionen typisk/ atypisk en teoretisk ballast, så den bliver håndterbar. Vi begynder med at ændre terminologien. Således vil vi fremover skelne mellem kongruent og inkongruent.

Den kongruente forbindelse mellem semantikken og leksikogrammatikken

"[...] is one in which this direct line of form to meaning to experience is maintained intact, as it is in young children's language like man clean car." (Halliday 1994: xix)

Den kongruente sammenhæng er den mest umiddelbare sammenhæng, fordi det er den sammenhæng, der respekterer sprogets grundlæggende fylogenetiske og ontogenetiske sammenhænge. Fylogenese betegner sprogets udvikling gennem evolution, mens ontogenese (som afspejler fylogenesen) betegner sprogets udvikling i den individuelle sprogbruger (jf. Halliday og Matthiessen 1999: 17). Et eksempel på en grundlæggende fylo- og ontogenetisk sammenhæng er den, at

"[...] 'noun' or 'verb' [...] are 'designating persons, places, things, states, or qualities' and '[...] express action or state', respectively." (Lyons 1977: 441)

En kongruent leksikogrammatisk realisering af en (semantisk) betydning karakteriserer således en realisering, der er typisk i et diakront snit. ${ }^{13}$

Med begrebsliggørelsen af kongruens kan vi nu præsentere teorien om den leksikogrammatiske metafor. En leksikogrammatisk metafor opstår, når en betydning (på det semantiske stratum) realiseres inkongruent (på det leksikogrammatiske stratum). Med Hallidays ord kan man lidt simpelt betragte en leksikogrammatisk metafor som "variation in the expression of a given meaning" (Halliday 1994: 342). Når vi skriver, at ovenstående betragtning er lidt simpel, hænger det sammen med konsekvensen af det naturlige forhold mellem det semantiske og det leksikogrammatiske stratum, nemlig at en ændring i leksikogrammatik medfører en ændring i semantik. Det er derfor mere præcist at opfatte den leksikogrammatiske metafor som en funktion i sproget, hvorved forskellige leksikogrammatiske realiseringer realiserer tæt beslægtede, men dog forskellige (semantiske) betydninger.

\subsection{Ytringsfunktionelle metaforer}

Ytringsfunktioner og ytringsfunktionelle metaforer er et særdeles komplekst område i sproget, fordi konteksten (typen af rolle, der spilles, i forhold til typen af sag, der udveksles) har direkte indflydelse på klassificeringen af en ytring som enten den ene, anden, tredje eller fjerde ytringsfunktion. Vi er således langt fra en situation, hvor de leksikogrammatiske karakteristika (og dermed det mest håndgribelige) spiller den afgørende rolle. Som en konsekvens heraf kan kriterierne for at skelne forekomme mere flydende end $\mathrm{i}$ andre dele af sprogbeskrivelsen, hvorfor det er væsentligt at gøre sig metodikken bag beskrivelsen - $\mathrm{i}$ dette tilfælde taksonomien over ytringsfunktionelle metaforer - klar. 
Thomas Hestbæk Andersen og Flemming Smedegaard, Interpersonel farvning i dansk

I forlængelse af fig. 2 og redegørelsen herfor fungerer de fire ytringsfunktioner som fire distinkte valg i et paradigme. Den paradigmatiske dimension muliggør, at vi kan betragte de fire ytringsfunktioner som forbundne - de eksisterer kun i kraft af forbindelsen med hverandre. En sådan betragtning kan skitseres ved at placere ytringsfunktionerne som poler i et koordinatsystem, som det er gjort i fig. 6 .

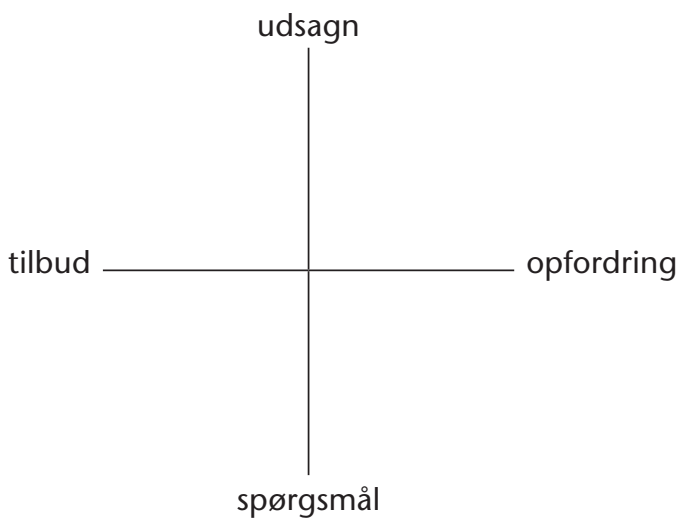

Fig. 6: Ytringsfunktioner i koordinatsystem

Koordinatsystemet åbner med sine to aksiale kontinua og fire kvadranter mulighed for en mere nuanceret ytringsfunktionel analyse af sætningerne i en tekst, end det er muligt at foretage ved hjælp af kassetænkningen bag fig. 2. Således kan de sætninger, der rummer en ytringsfunktionel tvetydighed, placeres i det brede rum mellem de forskellige ytringsfunktioner, ikke i den snævrere kasse (eller pol), som den enkelte ytringsfunktion udgør.

Placering i et koordinatsystem som ovenstående er netop, hvad Andersen har gjort ved i alt 115 ytringsfunktionelle metaforer (jf. Andersen 2003: 254ff.). Metodikken bag indplaceringen i koordinatsystemet har været sådan, at først er alle tilfældene blevet fremanalyserede (ud fra semantiske overvejelser) ud fra et tekstkorpus (i alt 76 tekster repræsenterende en række forskellige registre, såsom samtaler (herunder interviews), stillingsannoncer, tekniske manualer, vejledninger, lovforslag, avisartikler (reportager, ledere, kronikker), faglig information, EU-cirkulærer, nyhedsbreve, kommunalplaner og læserbreve). Enkelte ytringer er hentet fra forskellige elektroniske korpora, især VISL og Korpus 2000. Alene metaforiske ytringsfunktioner (altså ytringsfunktioner realiseret af en inkongruent sætningsstruktur) er medtaget. Dernæst er tilfældene blevet placeret i koordinatsystemet, således at afstanden mellem fx udsagn og opfordring er betragtet som et kontinuum, og det givne tilfælde er i kvadranten mellem de nævnte poler placeret i afstandsmæssigt forhold til den ytringsfunktion, det hovedsageligt realiserer. Resultatet af analyserne er gengivet nedenfor:

I kvadranten mellem udsagn og opfordring finder vi et tilfælde som Man skal forholde sig roligt (fra en artikel om strandede hvaler). Dette prototypiske tilfælde, som vi benævner den fremsættende opfordring, illustrerer, at denne opstår som en spænding mellem en 
Thomas Hestbæk Andersen og Flemming Smedegaard, Interpersonel farvning i dansk

opfordrende semantik og en leksikogrammatik (den deklarative sætningsstruktur), der kongruent hører udsagnet til.

I kvadranten mellem udsagn og tilbud finder vi et tilfælde som Okay Shaky, du får mit telefonnummer, hvis du kører endnu hurtigere (replik fra filmen Festen). Dette prototypiske tilfælde, som vi benævner det fremsættende tilbud, illustrerer, at dette opstår som en spænding mellem en tilbydende semantik og en leksikogrammatik (den deklarative sætningsstruktur), der kongruent hører udsagnet til.

I kvadranten mellem spørgsmål og opfordring finder vi et tilfælde som Kan man ikke anbringe et tilsvarende skilt på skydedøren til Hvilekupéen? (fra et læserbrev i Ud og Se). Dette prototypiske tilfælde, som vi benævner den spørgende opfordring, illustrerer, at denne opstår som en spænding mellem en opfordrende semantik og en leksikogrammatik (den polarinterrogative sætningsstruktur), der kongruent hører spørgsmålet til.

Hvad angår kvadranten mellem spørgsmål og tilbud findes der i det analyserede materiale ingen eksempler på leksikogrammatiske metaforer. Vi har således intet belæg for at postulere en metaforisk spændingszone mellem spørgsmålet og tilbuddet, og vi vil betragte kvadranten som tom, altså alene som en teoretisk/ spekulativ mulighed, ikke som en almindeligvis instantieret mulighed.

På selve aksen mellem udsagn og spørgsmål finder vi yderligere to typer af ytringsfunktionelle metaforer, nemlig hhv. det spørgende udsagn og det fremsættende spørgsmål.

Det spørgende udsagn, der kan illustreres af tilfældet Skal det voere billigere at voldtage end at stjoele? Skal det voere billigere at slå folk til invalider end at stjoele? (fra tale på politisk landsmøde), opstår som en spænding mellem en fremsættende semantik og en leksikogrammatik (den interrogative sætningsstruktur), der kongruent hører spørgsmålet til. Det spørgende udsagn kaldes også et retorisk spørgsmål. Leksikogrammatisk indikerer valget af interrogativstruktur, at vi har at gøre med et spørgsmål. Men betragtes det retoriske spørgsmål fra oven, er kun det ene af spørgsmålets to semantiske basiskriterier opfyldt, nemlig at det drejer sig om udvekslingen af information. Det andet basiskriterium for spørgsmålet - nemlig at den kommunikative rolle for afsender skal være at modtage er ikke opfyldt. For idet afsender stiller et retorisk spørgsmål, ønsker vedkommende ikke at modtage information. Afsender ønsker derimod at blive ved med at give information. Og som sådan ligner det retoriske spørgsmål udsagnet.

Det fremsættende spørgsmål, der kan illustreres af tilfældet Du har sagt, at man skal kalde magt ved sit rette navn? (portrætinterview med Frank Jensen), opstår som en spænding mellem en spørgende semantik og en leksikogrammatik (den deklarative sætningsstruktur), der kongruent hører udsagnet til.

I alt har dansk således potentialet til at konstruere fem forskellige typer af ytringsfunktionelle metaforer.

\subsection{Modalitetsmetaforer}

Hvad angår leksikogrammatisk modalitetsmetaforik, anfører Halliday, at 
Thomas Hestbæk Andersen og Flemming Smedegaard, Interpersonel farvning i dansk

"It is not always possible to say exactly what is and what is not a metaphorical representation of modality." (Halliday 1994: 355)

Modalitet og modalitetsmetaforik er således et komplekst område i sprogbeskrivelsen, og hvis vi skal nå til en klar afgrænsning af, hvad der konstituerer en leksikogrammatisk metaforisering af modalitet, må vi tage udgangspunkt i det i denne sammenhæng allermest fundamentale, nemlig hvad en kongruent realisering af modalitet er.

Som tidligere anført er det i dansk sådan, at modalitet realiseres kongruent af funktioner i Modus. Altså af enten Finitum (formet af et modalverbum) eller af en Modaladjunkt. Alle andre måder at realisere modalitet på er inkongruente - og dermed konstituerer disse måder metaforisk sprogbrug.

I dansk er der tre måder, hvorpå man kan realisere modalitet uden anvendelse af funktionerne i Modus, hvilket giver tre typer af modalitetsmetaforer nemlig (i) modalitetsom-kvalitet, (ii) modalitet-som-proposition og (iii) modalitet-som-kommentar.

(i) Modalitet-som-kvalitet opstår, når modalitet optræder som en kvalitet, fordi den realiseres inkongruent i Residual af en Adjunkt formet af et adjektiv. Ideationelt optræder denne Adjunkt som et Attribut. ${ }^{14}$

Modalitet fungerende som kvalitet optræder i sætningskløvninger, hvorfor vi ser den i konstruktioner som:

- Det er sandsynligt, at landsholdet vinder aftenens kamp.

- Det er usandsynligt, at ...

- Det er realistisk, at ...

- Det er urealistisk, at ...

- Det er muligt, at ...

- Det er toenkeligt, at ...

- Det er utoenkeligt, at ...

- Det er nødvendigt, at ...

I de syv første af ovenstående otte eksempler er det modalitetstypen mulighed \& sandsynlighed, der er metaforiseret, mens sidste eksempel er en metaforisering af modalitetstypen nødvendighed. Således findes denne type af leksikogrammatisk metafor ved inkongruente realiseringer af både modalisation og modulation, hvilket gør den særlig i forhold til de to øvrige typer af modalitetsmetaforer. Disse kan nemlig alene rumme modalitet af typen modalisation.

(ii) Modalitet-som-propositionsmetaforen opstår, når modalitet af typen modalisation ikke realiseres af enten en Modaladjunkt eller af Finitum formet af et modalverbum, men af en propositionsekstern markør med sætningsform. Modaliteten realiseres altså uden for den sætning og dermed proposition, som den modalt farver.

Den propositionseksterne markør, som er den leksikogrammatiske realisering i en modalitet-som-propositionsmetafor, har følgende karakteristika: (a) Subjektet er et 
Thomas Hestbæk Andersen og Flemming Smedegaard, Interpersonel farvning i dansk

1. persons pronomen, oftest i singularis, altså jeg, (b) verbalgruppens interpersonelle funktion er Finitum/Prædikator, (c) verbalgruppens ideationelle funktion er en Mental Proces, typisk synes, tror eller mener, og (d) verbalgruppens tempus er præsens, som i denne sammenhæng realiserer nutid.

Et tilfælde af ovenstående er følgende udsagn fra daværende Kirkeminister Johs. Lebech i en diskussion af indvandreres måde at organisere familielivet på, herunder udviklingen fra at bo mange generationer sammen (som også mange indfødte danskere har gjort tidligere) til ikke at bo sammen på tværs af generationerne:

Jeg tror, at vi vil se nøjagtig den samme udvikling hos indvandrere

Et sådan sætningskompleks ville umiddelbart - uden øje for metaforikken - kunne analyseres som følger:

\begin{tabular}{|l|l|}
\hline Jeg tror, & at vi vil se nøjagtig den samme udvikling hos indvandrere \\
\hline proposition 1 & proposition 2 \\
\hline
\end{tabular}

Skævheden i ovenstående analyse er, at der ikke er tale om to selvstændige propositioner, men i stedet om én proposition, der farves med en interpersonel modalitet. Dette bliver tydeligt, når vi føjer en Spørgemarkør til sætningskomplekset. Herved fremkommer følgende sætningskompleks:

Jeg tror, at vi vil se nøjagtig den samme udvikling hos indvandrere, vil vi ikke?

Spørgemarkøren adresserer ikke betydningen i det, der ovenfor blev analyseret som proposition 1, altså afsenders tro. Spørgemarkøren adresserer derimod betydningen i det, der ovenfor blev betragtet som proposition 2, nemlig om man fremover kommer til at opleve den samme udvikling hos indvandrere som hos indfødte danskere. Skulle Spørgemarkøren have adresseret betydningen af proposition 1, ville ytringen lyde:

* Jeg tror, at vi vil se nøjagtig den samme udvikling hos indvandrere, tror jeg ikke?

Og denne fungerer ikke. Funktionelt er det hverken passende, forståeligt eller rimeligt på ovenstående måde som ytrende subjekt at tro noget og i samme moment at gøre det usikkert, om man tror noget. Skal Spørgemarkøren adressere betydningen af at tro noget, er det nødvendigt, at det ikke er afsender, altså jeg, der tror noget, men derimod modtager eller en udenforstående person, altså enten $d u$ eller fx han. For ytringer som de følgende er funktionelt acceptable (i ytringerne optræder $g ø r$ som en proform af tror):

Du tror, at vi vil se nøjagtig den samme udvikling hos indvandrere, gør du ikke? Han tror, at vi vil se nøjagtig den samme udvikling hos indvandrere, gør han ikke? 
Thomas Hestbæk Andersen og Flemming Smedegaard, Interpersonel farvning i dansk

I forhold til ovenstående to ytringer vil det derimod ikke være funktionelt passende med en Spørgemarkør, der adresserer, om man vil se udviklingen eller ej:

* Du tror, at vi vil se nøjagtig den samme udvikling hos indvandrere, vil vi ikke?

* Han tror, at vi vil se nøjagtig den samme udvikling hos indvandrere, vil vi ikke?

Ved at efterprøve med en Spørgemarkør bliver det som ovenfor illustreret tydeligt, at ytringen Jeg tror, at vi vil se nøjagtig den samme udvikling hos indvandrere ikke er parallel med Du tror, at vi vil se nøjagtig den samme udvikling hos indvandrere eller Han tror, at vi vil se nøjagtig den samme udvikling hos indvandrere. Således er den første ikke blot en 1 . persons variant af de to sidste.

Den mentale tro-proces i Jeg tror, at vi vil se nøjagtig den samme udvikling hos indvandrere er afbleget i forhold til tro-processen i Du tror, at vi vil se nøjagtig den samme udvikling hos indvandrere og Han tror, at vi vil se nøjagtig den samme udvikling hos indvandrere. I stedet for at realisere den mentale proces at tro, realiserer jeg tror i stedet talerens holdning til det, som er den egentlige proposition (altså betydningen af proposition 2 i ovenstående analyse). Med andre ord betegner jeg tror metaforik af typen modalisation. Som Halliday utrykker det:

"[...] the speaker's opinion regarding the probability that his observation is valid is coded not as a modal element within the clause, but as a separate, projecting clause in a hypotactic clause complex. To the congruent form it probably is so corresponds the metaphorical variant I think it is so, with $I$ think as the primary or 'alpha' clause. The reason for regarding this as a metaphorical variant is that the proposition is not, in fact, 'I think'; the proposition is 'it is so'." (Halliday 1994: 354; vores fremhævning)

(iii) En modalitet-som-kommentarmetafor opstår, når modalitet af typen modalisation realiseres inkongruent af en Kommentaradjunkt formet af en præpositionalfrase. I dansk finder vi modalitet-som-kommentar i konstruktioner som ${ }^{15}$ :

- $\quad$ Efter min mening gør det kun sagen tifold voerre.

- $\quad$ Efter min opfattelse...

- $\quad$ Efter min overbevisning...

- $\quad$ Efter min vurdering...

- $\quad$ Efter min erfaring...

Ovenstående om leksikogrammatiske modalitetsmetaforer i dansk kan systemisk opsummeres med netværket i fig. 7. 
Thomas Hestbæk Andersen og Flemming Smedegaard, Interpersonel farvning i dansk

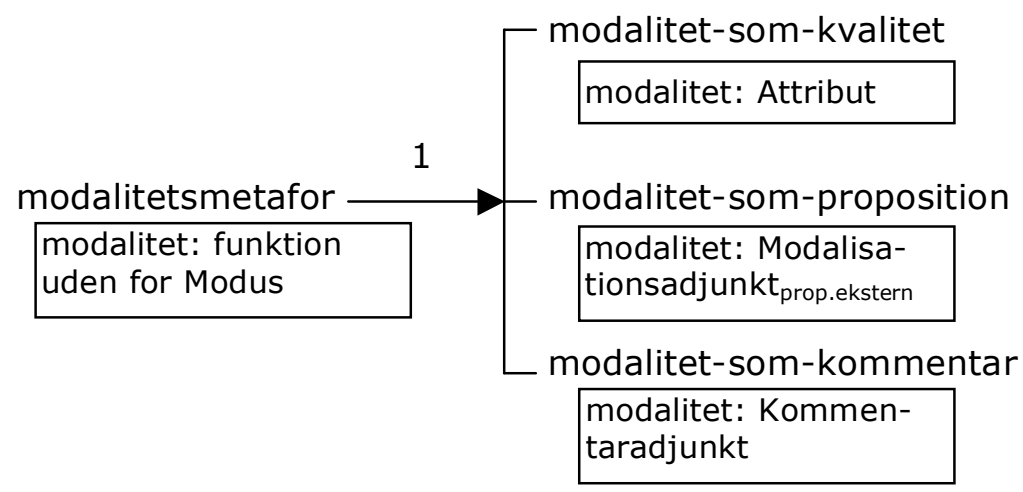

Fig. 7: Netværk for modalitetsmetaforer i dansk

\section{Afrundende bemarkNINGer}

I denne artikel har vi præsenteret de to mest centrale interpersonelle ressourcer i dansk, som farver en sproglig ytring, dels ressourcerne til udveksling af information mellem afsender og modtager i form af sprogets ytringsfunktioner, dels ressourcerne til at markere afsenders attitude til ytringen i form af modalitet, og vi har vist, hvordan disse ressourcer anvendes både i typiske og atypiske udgaver.

De to nævnte ressourcer er imidlertid ikke de eneste ressourcer, som farver en ytring interpersonelt. En anden ressource til interpersonel farvning er den farvning, som realiseres af den anvendte leksik, fx forskellen på at anvende det neutrale vinde i eksemplet Brøndby vandt 3-1 over FCK og så det værdiladede smadrede i Brøndby smadrede FCK med 3-1 eller forskellen på, hvilket beskrivende adjektiv man vælger fra synonymordbogen til at beskrive en person. I en synonymordbog (Synonymordbogen 1976) sammenstilles adjektivet dygtig med begavet, duelig, ferm, fiks, fingernem, flink, fremmelig, god, habil, kapabel, kompetent, kundskabsrig, stiv i papirerne, skarp, smart, velbevandret, virtuos og sin opgave voksen, og alt afhængig af, hvilket af disse ord afsender vælger, tillægges den omtalte person forskellige associerende bedømmelser og vurderinger. Det er også denne type mekanismer, man ofte benytter i forbindelser med overdrivelser (fx Hun er helt ufattelig, overdrevet smuk) og underdrivelser (fx Det er noesten ikke noget).

Den type interpersonelle farvningsressourcer, som kort er omtalt i ovenstående eksempler, benævner vi i systemisk funktionel lingvistik for evaluering (engelsk: appraisal). Det ligger uden for rammerne af denne artikel at uddybe det for dansk endnu blot præliminært beskrevne evalueringsfelt nærmere ${ }^{16}$, og omtalen ovenfor har kun til formål afslutningsvis at påpege, at der også findes andre former for interpersonelle farvninger end de, vi har gennemgået i artiklen. 
Thomas Hestbæk Andersen og Flemming Smedegaard, Interpersonel farvning i dansk

\section{LITTERATUR}

Andersen, Thomas Lund (2000), Stjernernes tale - register i teori og praksis, Odense: Syddansk Universitet (= Odense Working Papers in Language and Communication, nr. 21).

Andersen, Thomas Hestbæk (2003), Spoendinger i sproget - Om leksikogrammatiske metaforer i dansk, Syddansk Universitet: Institut for Sprog og Kommunikation (Ph. D.-afhandling, tilgængelig på: www.humaniora.sdu.dk/sfl/index.htm]).

Andersen, Thomas et al. (2001), Sproget som ressource - Dansk systemisk funktionel lingvistik i teori og praksis, Odense: Odense Universitetsforlag.

Austin, J. L. (1962), How to do things with words, Oxford: Oxford University Press.

Bundesen, Ditte Bjerrisgaard (2002), Sproglige roser \& verbale toesk - evaluering $i$ dansk, Syddansk Universitet: Center for Nordiske Studier (kandidatspeciale, tilgængelig på www.humaniora.sdu.dk/sfl/index.html).

Davidse, Kristin (1997), „The Subject-Object versus the Agent-Patient asymmetry“, $l b$. leuven contributions in linguistics and philology, 86/3-4 (1997), pp. $413-431$.

Halliday, Michael (1973), Explorations in the functions of language, London: Arnold.

Halliday, Michael (1978), Language as social semiotic, London: Arnold.

Halliday, Michael (1979), "Modes of meaning and modes of expression: types of grammatical structure, and their determination by different semantic functions", in: Allerton, D.J., Edward Coney, David Holdcroft (eds.) (1979), Function and context in linguistic analysis - A festschrift for William Haas, Cambrigde: Cambridge University Press, pp. 56 - 79.

Halliday, Michael (1984), "On the Ineffability of Grammatical Categories", in: Halliday, M.A.K. (2002), On Grammar. Collected Works of M.A.K. Halliday, vol. 1, London: Continuum, pp. $291-322$.

Halliday, Michael (1994), Introduction to Functional Grammar, 2. ed., London: Arnold.

Halliday, Michael (1996), "On Grammar and Grammatics", in: Hasan, Ruqaiya, Carmel Cloran, David Butt (eds.) (1996), Functional Descriptions - Theory in practice, Amsterdam: John Benjamins Publishing Company, pp. 1 - 38.

Halliday, Michael (1998), "Grammar and Daily Life: Concurrence and Complementarity", in: Halliday, M.A.K. (2002), On Grammar. Collected Works of M.A.K. Halliday, vol. 1, London: Continuum, pp. $369-383$.

Halliday, Michael (2002), "A personal perspective", in: Halliday, M.A.K. (2002), On Grammar. Collected Works of M.A.K. Halliday, vol. 1, London: Continuum, pp. 1 16.

Halliday, Michael, Ruqaiya Hasan (1985), Language, context and text: Aspects of language in a social-semiotic perspective, Geelong: Deakin University Press.

Halliday, Michael, Christian Matthiessen (1999), Construing Experience through Meaning, London: Cassell.

Halliday, Michael, Christian Matthiessen (2004), Introduction to Functional Grammar, 3. ed., London: Arnold.

Hasan, Ruqaiya (1985), A systemic-functional approach, Macquarie University, udkast ("revised and enlarged version of a paper presented at the XIIth International Systemic Workshop").

Hjelmslev, Louis (1993), Omkring sprogteoriens grundloeggelse, København: The Linguistic Circle of Copenhagen.

Jakobsen, Lisbeth Falster (1995), “Tag sprog alvorligt!”, NyS, 20 (1995), pp. 11 - 39. 
Thomas Hestbæk Andersen og Flemming Smedegaard, Interpersonel farvning i dansk

Lyons, John (1977), Semantics, 2 vols., Cambridge: Cambridge University Press.

Martin, J. R., David Rose (2003), Working with Discourse, London: Continuum.

Matthiessen, Christian M.I.M. (1992), Lexicogrammatical Cartography: English Systems, Sydney: University of Sydney (Draft 5).

Morris, Charles (1971), Writings on the General Theory of Signs, Haag: Mouton.

de Saussure, Ferdinand (1949), Cours de linguistique générale, Paris: Payot.

Searle, J. R. (1969), Speech acts: an essay in the philosophy of language, Cambridge: Cambridge University Press.

Smedegaard, Flemming (2002), Verden i sproget, TRANSITIVITET i dansk - en systemisk funktionel beskrivelse, Syddansk Universitet: Institut for Sprog og Kommunikation (Ph.D.-afhandling, tilgængelig på www.humaniora.sdu.dk/sfl/index.html).

Synonymordbogen (1976), København: Politikens Forlag.

Thibault, Paul J., Theo van Leeuwen (1996), "Grammar, society and the speech act: Renewing the connections", Journal of Pragmatics, 25, pp. $561-585$.

Wittgenstein, Ludwig (1958), Philosophische Untersuchungen, Frankfurt/M.: Suhrkamp.

\section{NOTER}

1 Halliday påpeger, at nyere studier viser, at sprog og hjerne udvikles sammen (jf. Halliday 1998: 370). Vi kan derfor ikke slippe for sproget, og vi kan intet gøre uden det. Vores tankegang - altså vores betydningsskabelse - er sammenvævet med sprogliggørelse (jf. Halliday 1996b: 8 og 2002: 3). Dette synspunkt har Andersen tidligere forfægtet, nemlig i Andersen (2000).

2 Inden for systemisk funktionel lingvistik betragter vi grammatik og leksik under ét (jf. Halliday 1996: 22 og 1994: 15). Hermed bryder den systemisk funktionelle teori med Morris' ofte refererede tredeling i syntaks, semantik og pragmatik (Morris 1971: del 1), der første gang formuleredes i 1938, idet leksikogrammatik ikke blot er syntaks.

3 Skal vi trække en tråd til Hjelmslev (1993), som Halliday selv nævner som en af sine primære inspirationskilder (Halliday 1994: xxvi), kan leksikogrammatikken betragtes som indholdsform, mens semantikken er indholdssubstans.

4 "Ytringsfunktioner" (efter Hallidays "speech function", jf. fx Halliday 1994: 69), "Speech Acts" (jf. Austin 1962 og Searle 1969) og "Sprogspil" (jf. Wittgenstein 1958: §23) - kært barn har mange navne, fristes man til at sige. I hvert fald er mange taksonomier (og mange flere end de nævnte) over sprogets ytringsfunktioner blevet postuleret gennem tiden. Den systemisk funktionelle taksonomi har en styrke, fordi den direkte modellerer og beskriver sammenhængen mellem kontekst, ytringsfunktion og realiserende leksikogrammatik. Hvad angår fundering i leksik og grammatik er ingen anden beskrivelse af ytringsfunktioner lige så rig som den systemisk funktionelle (jf. Thibault og van Leeuwen 1996).

5 Sammenhængen mellem Modus og Residual er den, som Davidse med udgangspunkt i Langacker beskriver som en "type specification" (: Residual), der forankres af et "grounding element" (: Modus) (1997: 420).

$6 \quad$ Halliday og Matthiessen betegner Subjektet som "the element the speaker makes responsible for the validity of what he is saying" (2004: 59), hvilket skal forstås på den måde, at "the truth or falsehood of the statement is vested in [the Subject]" (2004: 55).

7 Finitum/Prædikator er en fusion af sætningsfunktionerne Finitum og Prædikator. Finitum har vi defineret i teksten. Prædikator, som er en del af Residual, er defineret som den leksikalske del af verbalgruppen. En uddybende beskrivelse af såvel Prædikator som hele Residual findes i Andersen et al. (2001: 44ff.).

8 Vores beskrivelse af modalitet i dansk i denne artikel, herunder kategoriseringen af forskellige typer af modalitet, er udtryk for vores seneste udforskning af modalitet, og beskrivelsen 
Thomas Hestbæk Andersen og Flemming Smedegaard, Interpersonel farvning i dansk

varierer således på en række punkter fra vores hidtidige beskrivelser heraf, bl.a. i Andersen et al. (2001).

$9 \quad$ Modalisation er lig den traditionelle epistemiske modalitet.

10 Modulation er lig den traditionelle deontiske modalitet.

11 For en detaljeret gennemgang af Cirkumstantialeadjunkter se Smedegaard (2002: kap. 8).

12 Se Andersen (2003) for en både teoretisk og deskriptiv gennemgang af alle hovedtyper af leksikogrammatiske metaforer i dansk.

13 Se Andersen (2003: 192ff.) for en diskussion af kongruens.

14 Af pladshensyn afholder vi os i denne artikel fra at beskrive sprogets ideationelle ressourcer og dermed også leksikogrammatikkens ideationelle funktioner. Se Andersen et al. (2001: kap. 3-4) og Smedegaard (2002) for en beskrivelse af den ideationelle metafunktion.

15 efter kan erstattes af ifølge.

16 For en mere udførlig gennemgang af evaluering henvises til Andersen et al. (2001: 232ff.), Bundesen (2002) og Martin \& Rose (2003: 22ff.). 